\title{
Arriving at pronunciation accuracy in singing English songs: Hijaiyah consonants as the mediation
}

\author{
Iqbal Maulanaa ${ }^{\mathrm{a}, 1}$, Riski Lestiono ${ }^{\mathrm{b}, 2}$, Triastama Wiraatmaja $\mathrm{a}^{\mathrm{c}, 3}$, Rosalin Ismayoeng Gusdian $\mathrm{d}^{\mathrm{d}, 4^{*}}$ \\ abcd Universitas Muhammadiyah Malang, Jalan Raya Tlogomas 246 Malang, 65144, Indonesia \\ 1 maulanaiqbal05@gmail.com; ${ }^{2}$ riskilestiono@umm.ac.id; ${ }^{3}$ triastama@umm.ac.id; \\ ${ }^{4}$ rosalingusdian@umm.ac.id \\ * Corresponding Author
}

\begin{tabular}{l}
\hline INFO ARTIKEL \\
\hline Sejarah Artikel: \\
Diterima: 6 Agusuts 2021 \\
Direvisi: 3 September 2021 \\
Disetujui: 21 September 2021 \\
Tersedia Daring: 31 Oktober \\
2021 \\
\hline
\end{tabular}

ABSTRAK

Kata Kunci:

Konsonan Bahasa Arab

Konsonan Bahasa Inggris

Konsonan Hijaiyah

Lagu-lagu Bahasa Inggris

Pengucapan Kata

\begin{abstract}
Bahasa di dunia sangat beragam, tetapi dimungkinkan adanya persamaan. Sebagai pelajar, sangat penting untuk mempelajari fonologi dan fonetik dari berbagai bahasa untuk membandingkan dan menyamakan satu dengan yang lainnya. Bahasa Inggris dan Arab samasama memiliki struktur linguistik terbesar dari semua bahasa di dunia. Kedua bahasa tersebut memiliki kesamaan ciri, seperti konsonannya. Dari persamaan tersebut, Lestiono dan Gusdian (2017) melakukan penelitian terhadap konsonan bahasa Arab dalam membantu pengucapan bahasa Inggris, yang dikenal sebagai tabel kosonan bahasa Inggris-Hijaiyah. Tujuan dari penelitian ini adalah untuk mengetahui pengucapan dari delapan anggota paduan suara universitas dalam menyanyikan lagu-lagu bahasa Inggris sebelum dan sesudah pengenalan konsonan Hijaiyah sebagai mediasi. Dalam penelitian ini digunakan studi kasus, yang termasuk dalam desain kualitatif yang digunakan dalam mencapai pengucapan yang dibangun oleh subjek penelitian melalui observasi, analisis, dan deskripsi. Objek penelitian ini adalah bunyi konsonan yang dihasilkan oleh peserta penelitian saat menyanyikan lagu "When I Sing" oleh Russel Robinson dan Charolette Lee dan "The Seal Lullaby" oleh Eric Whitacre dan Rudyard Kipling. Instrumen yang digunakan adalah dokumen analisis. Dalam analisis ditemukan adanya partisipan yang salah dalam mengucapkan kosa kata yang ditargetkan sebelum diperkenalkan dengan konsonan Hijaiyah. Setelah pengenalan konsonan Hijaiyah sebagian besar peserta terdengar akurat. Hal ini dapat disimpulkan bahwa konsonan Hijaiyah dapat memfasilitasi anggota paduan suara mahasiswa untuk belajar dan menghasilkan kata-kata bahasa Inggris yang akurat saat bernyanyi.
\end{abstract}

Keywords:

Arabic Consonants

English Consonants

English Songs

Hijaiyah Consonants

Pronunciation

\begin{abstract}
Language in the universe is various; however, it does not close the possibility that each languages have an equation. As a learner, it is crucial to learn the phonology and phonetics of some languages to compare and equalize one another. English and Arabic both have the biggest linguistic construction. Both languages have the sameness of characteristics such as some of their consonants. From those similarities, Lestiono and Gusdian (2017) conducted a study on Arabic Consonant sounds to arrive at English Pronunciation, known as English-Hijaiyah consonant corresponding chart. The objective of the current research is to discover the pronunciation of eight university choir members in singing English songs before and after the introduction of Hijaiyah consonants as the mediation. In this present study acquire a case study, which is included to qualitative design that was used in arriving at the pronunciation constructed by the research subjects through observation, analyzation, and description.. The research objects were the consonant sounds produced by research
\end{abstract}




\begin{abstract}
participants while singing "When I sing" by Russel Robinson and Charolette Lee and 'The Seal Lullaby" by Eric Whitacre and Rudyard Kipling. The instrument was document analysis. In the findings, participants mispronounced many of the targetted words before they were introduced to Hijaiyah consonants as the mediation. Whereas, the pronunciation after the introduction showed that most of the participants sounded correct. This can be concluded that Hijaiyah consonants can facilitate the university student choir members to learn and produce accurate English words while singing.
\end{abstract}

(C) 2021, Maulana, Lestiono, Wiraatmaja, \& Gusdian This is an open access article under CC-BY-SA license mediation. Satwika : Kajian Ilmu Budaya dan Perubahan Sosial, 5(2), 303-316, https://doi.org/10.22219/satwika.v5i2.17666

\section{Introduction (Pendahuluan)}

Language in the universe is various; however, it does not close the possibility that each language has an equation. As a learner, it is crucial to learn the phonology and phonetics of some languages to compare and equalize one another. Dajani \& Omari $\underline{(2013)}$ assert that the age of globalization today helps greatly within the spread of languages and encourages modern generations to accumulate the skill of learning one language and benefiting from that materially, besides realizing the factor of social mobility.

English and Arabic both have the biggest linguistic construction. English is the West language of the Germanic subfamily of Indo-European languages, and Arabic belongs to the Semitic family (Yeaqub, 2018). These two languages can be categorized into typologies. Language typology identifies similarities and differences among languages of the whole world (Moravcsik, 2012). English and Arabic have the sameness of characteristics, such as some of their consonants. When different languages are compared, they show similarities, one of them is speech sounds (Gusdian \& Lestiono, 2018).

English and Arabic, which are distinct languages as they got here from different origins, surprisingly share some similar consonants (Javed, 2013). From those similarities, Lestiono and Gusdian (2017) studied Arabic Consonant sounds to arrive at English Pronunciation (figure 1). They have classified the likeness in consonant sounds between English and Arabic that helps reach out to the pronunciation accuracy. They have

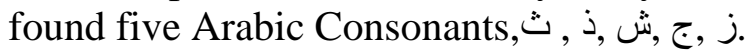

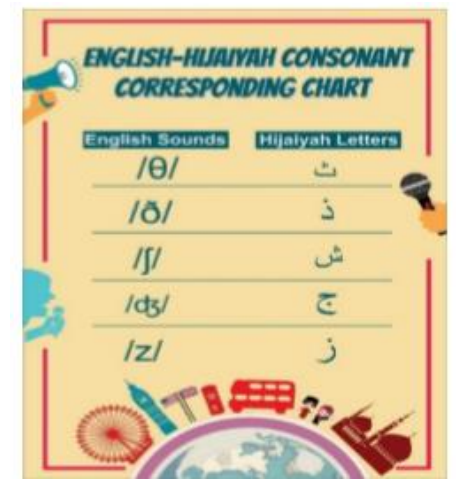

Figure 1. English-Hijaiyah consonant corresponding chart (Gusdian, M.A \& Lestiono, 2019)

For Indonesian students, pronouncing English words accurately is challenging. It is because of the differences between mother tongue and English phonological (Mulatsih, 2018). Another case study was conducted by Mulansari et al. (2014) declared that the most problematic tense-lax sound for the Indonesian 'student and factors made them unable to produce words correctly. In the study, the Indonesian students were influenced by some causes. First, Bahasa 
Indonesia does not distinguish between tense and lax sounds. Second, the students did not understand the regulation of English vowel sounds. Third, the students did not have much curiosity to learn more about English. This is supported by Sari et al. (2017) in their books. They state that when Indonesian students learn English as a foreign language, some speech sounds do not exist in the Indonesian phonological system and produce some unique words. for this reason, Indonesian learners often replace particular sounds that are difficult to pronounce. Also, it is due to the different phonological systems in English and Indonesian.

Riyani \& Prayogo (2013) conducted a study that released Indonesian singers' pronunciation errors when performing English songs. There are 506 mistakes out of the 2,569 words. Some elements need to be considered in singing, such as intonation, vocal quality, resonation, phonation, body posture, breathing, and articulation. From the case study by Riyani \& Prayogo (2013), most singers often ignore the articulation of the words that exist in the song. The pronunciation error effect to the singing technique made the song not heard clearly, and the message was not delivered. The singing technique involves the work of Jaw structure, stomach contractions, and airways in use (Dayme, 2009). The approach of learning English using songs can become a stimulating learning process because songs can bring an atmosphere for the learner (Supeno, 2008). The learning atmosphere is important, which is easily achieved with some fun activities, for example, singing songs. Singing accommodates the English learner to practice listening skills, produce the words, expressions, and practice their pronunciation (Dzanic \& Pejic, 2016). Farmand \& Pourgharib (2013) also revealed that students learning English through songs improved their pronunciation skill.

A Student Choir at the University of Muhammadiyah Malang is chosen as the subject of this study. In the preliminary observation, most of the singers made mistakes in pronouncing the lyrics when they were singing English songs. It is quite understandable because there was no English pronunciation learning. The singers sang the lyrics based on their knowledge. From the background, the researchers wanted to investigate the lyrics' pronunciation accuracy while they were singing. The implementation of the EnglishHijaiyah corresponding consonant chart by Gusdian \& Lestiono (2018) is used as a mediatory to complete before and after the choir is introduced to this concept.

In the previous study, Gusdian \& Lestiono (2018) The Use of Arabic Consonant Sounds to Arrive at English Pronunciation: A Case Study on Indonesian EFL Students in Tertiary Level. The study is about how the Arabic consonants are applied to college students learning English. Compared to this current study, the focus is on discovering the pronunciation of student choir members in singing English songs prior to and after the introduction of Hijaiyah consonants as the mediation.

Also from the previous study by Lestiono \& Gusdian (2017) conducted a study on How Arabic consonant sounds were applied in between student from Islamic-based school and regular school. This study focuses on how Arabic consonant sounds could influence them to pronounce English words. As a result, Indonesian EFL students with an Arabic knowledge background show more accurate pronunciation. Additionally, Lestiono and Gusdian (2017) showed that the acknowledgment of Arabic they got from an Islamic-based school affected their pronunciation. Meanwhile, it can be concluded that Arabic phonological accommodate Indonesian Efl students to pronounce a word.

Pronunciation is the key point of departure for all spoken languages, as thoughts have to be communicated in sound to be understood and become a word that can be transmitted to another. Pronunciation is a much more critical and widespread communication characteristic than is generally recognized (Pennington \& 
Rogerson-Revell, 2019). Acceptably, pronunciation is an essential aspect for people to produce the correct meaning of words. Pronunciation is important for the learner's competence and the most significant language instruction features (Gilakjani, 2016).

Some other scholars further propose some different definitions of pronunciation. Pennington and Richards (1986) point out that pronunciation is the articulation of individual sounds, which is closer coverage to the stress and intonation patterns of the target language (cited in Kosasih, 2017). It is related to how the voice is projected and in its comprehensive definition. Additionally, how a language can be delivered successfully depends on how one could give clear sound patterns within a communication. Kelly (in Sihombing, 2013) stated that pronunciation is the proficiency to utilize the stress, rhythm, and intonation of spoken language. Pronunciation is the apparent goal of oral communication (Gilakjani, 2016). Lindsay also said that language tones, stress, rhythm, and intonation are supra-segmental characteristics that involve pronunciation (cited in Jahan, 2003).

Learning a target and foreign language is challenging for beginners. Gilakjani et al. (2011) found that many English language learners have primary difficulties toward English Pronunciation, on the contrary, after years of learning the language. Indonesian learners have a struggle with spelling words. It occurs by the differences of linguistic features in their mother language. Kosasih (2017) explains that Indonesian students' hardship appears in spelling English words because it happens from the unfamiliar phonemes between English phonemes and Bahasa Indonesia phonemes. Accordingly, the differences between the two phonemes create difficulties for local students in achieving native English sounds.

Good pronunciation users (GPU) agree that English pronunciation learning's success requires the right strategies of learning pronunciation (Szyszka, 2015). They preferred active techniques, for example, repetition, imitation, and singing songs, which are parts of the learners' pronunciation skills. Furthermore, GPU also has its individualized approach to pronunciation learning strategies, such as talking in English independently, playing word spelling, transcribing, and reading aloud. Szyszka $\underline{(2015)}$ also asserted some plans that GPU avoids, for example, making a record of their voices to listen to pronunciation and arrange songs to memories the pronounced words. These less favored PLS are perhaps instances of very particular techniques that are less commonly used because they need more time.

Today's dilemma is choosing either putting fluency or accuracy first as the aspects of the English language. Both do not always come together when learning English. For example, students try to spell new words correctly while focusing on how to speak smoothly. It is difficult to compare these two approaches as they have strengths and weaknesses.

According to the Oxford dictionary, fluency is characterized as the quality of being fluent, especially recognizing oneself accurately and articulately. The perception of fluency,' involving the variant 'fluent,' is frequently used to characterize language proficiency. It is used to the skills in native and second language learners (Simensen, 2010). Fluency in the production of sounds and other aspects of pronunciation is equitably essential. The word fluency, described as the ability to use the language quickly and confidently without too much uncertainty or too many unnatural gaps, causes communication barriers (Bailey \& Nunan, 2019). Communication barriers make the messages not be received precisely to convey their information, ideas, and thoughts (Usha, 2016). There are five types of barriers: attitudinal barriers, behavioral barriers, cultural barriers, language barriers, and environmental barriers. In other words, fluency is an expectation for people who want to be fluent in the target language they 
have expanded their time and resources to acquire.

Accuracy, however, is described in the Oxford dictionary as the standard or state of correctness or precision. Referencing the teachingnglish.org.uk website of the British Council, accuracy refers to the proper usage of spoken language, involving the use of grammar, pronunciation, and vocabulary. Accuracy consists of speech, grammar, and pronunciation through some activities (Derakhshan et al., 2016). In other terms, accuracy can speak or write without any grammatical, vocabulary, punctuation, or other mistakes.

Most learners find that it is challenging to produce pronunciation accurately and fluently together. Fluency measures how a person can speak smoothly and efficiently without making mistakes, while accuracy in speaking counts how correctly using grammar in speech (Kumar, 2013). Speaking is a production skill involving two main categories: accuracy and fluency (Derakhshan et al., 2016). Accuracy strategies encourage the thoughtful use of the expression, and the content is supposed to assist students in understanding how English works. However, fluency exercises invite them to take on the role-playing involvement of various characters and proceed with dialogue in their way. That is to mention, fluency exercises enable free speech (Shen, 2013). Approaches, accuracy and fluency, are essential in speaking, how a learner can pay attention and practice.

A foreign language is a language not commonly spoken in the country of the speaker. All people should have the ability to learn more than one language. There will be many impacts if people are mastering languages, like communicating to everyone and everywhere in the universe. The largest language by many speakers is English.

English is an international language. A language acquires a genuinely global status when it develops as a role recognized in each country (Crystal, 2003). People could find the English language on social media, such as an article on Twitter,
Instagram's caption, etc. Whenever you are traveling abroad, you communicate with people using English. Using English has become a lingua when they do business with other business partners from different countries. For example, people in Eastern countries speak English because many tourists come to their country, which becomes common.

English and Arabic are different in cultures. However, some factors have categorized languages through their differences into some language groups, and they share some similarities in which one of them is speech sounds (Gusdian \& Lestiono, 2018). A comparative study conducted by Yeaqub (2018) explains that English and Arabic have similar sounds, like $/ \theta /, / /$, and /J/ do exist in both languages. Therefore, these similarities can help Arabic students to speak English correctly. As related to the study, Gusdian \& Lestiono (2018) surveyed Indonesian EFL students in producing English words based on their understanding of Arabic consonant sounds. The study's result believed that Arabic Consonant sounds assist Indonesian EFL students in pronouncing English words.

There are 24 consonant sounds in English (table 1). These consonants are:

Table 1. Consonant sounds in English (Adapted from Al-Zoubi, 2019)

\begin{tabular}{cc}
\hline Place of Articulation & Consonants \\
\hline bilabial & $\mathrm{p}, \mathrm{b}, \mathrm{m}, \mathrm{w}$ \\
labiodental & $\mathrm{f}, \mathrm{v}$ \\
dental & $\mathrm{\partial}, \mathrm{\theta}$ \\
alveolar & $\mathrm{t}, \mathrm{d}, \mathrm{r}, \mathrm{n}, \mathrm{l}, \mathrm{s}, \mathrm{z}$ \\
palatals & $\mathrm{J}, \mathrm{f}, \mathrm{s}, \mathrm{d}, \mathrm{j}$ \\
velars & $\mathrm{k}, \mathrm{g}, \mathrm{y}$ \\
glottal & $\mathrm{H}$ \\
\hline
\end{tabular}

In Arabic, there are 29 consonants (table 2). These are listed below:

Table 2. Consonant in Arabic (Adapted from $\underline{\text { Sabir \& }}$ Alsaeed, 2014)

\begin{tabular}{ll}
\hline Place of Articulation & Consonants \\
\hline bilabial & $b, m, w$ \\
denti-alveolar & $t, d, t, d$ \\
velar & $K$ \\
\hline
\end{tabular}




\begin{tabular}{ll}
\hline palate-alveolar & 3, $\int$ \\
uvular & $\mathrm{q}, \mathrm{\text { }}, \mathrm{x}, \mathrm{r}$ \\
alveolar & $\mathrm{1}, \mathrm{n}, \mathrm{s}, \mathrm{S}, \mathrm{z}, \partial$ \\
labio-dental & $\mathrm{F}$ \\
inter-dental & $\theta$, ð \\
pharyngeal & h̆,, \\
glottal & $\mathrm{H}$ \\
palatal & $\mathrm{J}$ \\
labio-velar & $\mathrm{W}$ \\
epiglottal & $?$ \\
\hline
\end{tabular}

Every language has two sound systems, i.e., consonant and vowel sounds. From the data above, English has 24 consonant sounds while Arabic has 28 Consonant sounds. English and Arabic are classified into three fields: voicing, place of articulation, and manner of expression. Despite the differences in both languages, English and Arabic consonants share some similarities; for example, $/ \theta /, / \mathrm{d} /, / \mathrm{J} /, / \mathrm{d} z /$, and/z/sounds, which exist in Arabic and English. In Arabic, the sound of $/ \theta /$ is similar to /ث/, /ð/ as /ذ/, /S/ as /ش/,/dz/, and /z/ as $/ j /$, from these similarities, in this present study is genuinely used as the learning media that would help learners in Indonesia who could read Hijaiyah sounds to study pronunciation, especially to pronounce English words. Therefore, the aim of this study is to discover the pronunciation of the Gitasurya student choir in singing English songs prior to and after the introduction of Hijaiyah consonants as the mediation.

\section{Method}

In this present study acquire a case study, which is included in the qualitative design that was used in arriving at the pronunciation constructed by the research subjects through observation, analysis, and description. The subjects of this current study were eight members of the student choir at the University of Muhammadiyah Malang. To fulfill this study, there are some criteria for the participants. The participants come from various faculties and at least have taken one year of English for Specific Purposes program. The participants were divided into four vocal types; there are soprano, alto, tenor, and bass, in accordance with the song's partitur. Two songs chosen by the researcher are 'When I sing - Russel Robinson, Charolette Lee 'and 'The Seal Lullaby - Eric Whitacre, Rudyard Kipling'. After the investigation, these two songs are chosen as the lyrics comprise English-Hijaiyah consonants and easily to sang by the participants. The songs are printed in the form of a music score.

There is a total of 29 words from two songs, 16 words in 'When I Sing' and 13 words in the song 'The Seal Lullaby'. These words were identified according to the English-Hijaiyah consonants chart. Three

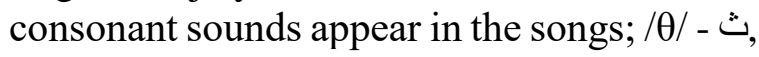
/ð/ - ذ, and / / - ش. .

Moreover, the instrument that specifically used was document analysis. They were related to the present study; the data being investigated in song lyrics validated by a linguistics expert in phonology.

These singers were to record their voice while singing songs before and after being introduced to English-Hijaiyah consonants. The researchers introduced the English-Hijaiyah consonant chart to the participants. To complete the understanding of the participants, it took 20-30 minutes. The time included introduction, application, and implementation of English-Hijaiyah consonants from the song's lyrics into singing.

After being recorded and transcribed, the transcription was analyzed in the form of tables in order to find out how these singers produced the targeted sounds in pronouncing several specific words.

\section{Result and Discussion}

\subsection{English Pronunciation before the Introduction of Hijaiyah Consonants}

First, this research was initiated by determining the Hijaiyah-consonant sounds that appeared in two songs already determined by the researchers. The songs are: 'When I sing - Russel Robinson, Charolette Lee and 'The Seal Lullaby - Eric Whitacre, Rudyard Kipling.'Then, the researchers were assisted 
by an expert in phonology in dissecting lyrics. After identifying the lyrics to the songs, it turns out that there are three types of Hijaiyahconsonant voices with 29 words targeted. For example, in the 'When I Sing' song, there are two English and Hijaiyah consonants. First is/ $\theta /-/ /$, which appears in 16 words, and/ð/ - /ذ/ comes out in nine words of the lyric. In the second song, 'The Seal Lullaby,' there are three identified English, and Hijaiyah consonants, which are: $/ \theta /-/ /$ in four words, /ð/ - / spread in nine words, the last, /J/ - / appearing in two words.

The researchers came to the individual sections to conduct the research process.
Then, the researchers asked the participants to sing the songs to get results on their pronunciation. Finally, the researchers recorded the singing activity in the form of a sound recording, where the next one would be transcribed in table form. Then, the researchers got the results as in table 3 and table 4 below. In table 3 , six out of eight participants (SF, RF, CY, AY, HA, and NH) could sing the song "When I Sing". While, in the table 4, six out of eight singers (SF, RF, $\mathrm{NA}, \mathrm{AK}, \mathrm{HA}$, and $\mathrm{NH}$ ) could sing the song "The Seal Lullaby".

Table 3. Consonant sounds produced in the song 'When I Sing' before the Introduction of Hijaiyah Consonants

\begin{tabular}{|c|c|c|c|c|c|c|c|c|c|}
\hline \multirow{2}{*}{ No } & \multicolumn{3}{|c|}{ Consonant sounds } & \multirow{2}{*}{ SF } & \multirow{2}{*}{ RF } & \multirow{2}{*}{$\mathrm{CY}$} & \multirow{2}{*}{ AY } & \multirow{2}{*}{ HA } & \multirow{2}{*}{$\mathrm{NH}$} \\
\hline & Consonant & Words & Line & & & & & & \\
\hline \multirow{7}{*}{1.} & \multirow{7}{*}{ / / / - / / } & thousand & 3 & $/ \mathrm{t} /$ & $/ \mathrm{t} /$ & $/ \mathrm{t} /$ & $/ \mathrm{t} /$ & $/ \mathrm{t} /$ & $/ \mathrm{t} /$ \\
\hline & & with & 13 & $/ \mathrm{t} /$ & $/ \mathrm{t} /$ & $/ \mathrm{t} /$ & $/ \mathrm{t} /$ & $/ \mathrm{t} /$ & $/ t /$ \\
\hline & & with & 14 & $/ \mathrm{t} /$ & $/ t /$ & $/ \mathrm{t} /$ & $/ t /$ & $/ t /$ & $/ t /$ \\
\hline & & breath & 14 & $/ \mathrm{t} /$ & $/ \mathrm{t} /$ & $/ \mathrm{t} /$ & $/ \mathrm{t} /$ & $/ \mathrm{t} /$ & $/ t /$ \\
\hline & & with & 15 & $/ \mathrm{t} /$ & $/ \mathrm{t} /$ & $/ \mathrm{t} /$ & $/ \mathrm{t} /$ & $/ \mathrm{t} /$ & $/ \mathrm{t} /$ \\
\hline & & with & 21 & $/ \mathrm{t} /$ & $/ \mathrm{t} /$ & $/ \mathrm{t} /$ & $/ \mathrm{t} /$ & $/ \mathrm{t} /$ & $/ \mathrm{t} /$ \\
\hline & & thousand & 11 & $/ \mathrm{t} /$ & $/ \mathrm{t} /$ & $/ \mathrm{t} /$ & $/ \mathrm{t} /$ & $/ \mathrm{t} /$ & $/ \mathrm{t} /$ \\
\hline \multirow{9}{*}{2.} & \multirow{9}{*}{ /ð/ - / / } & within & 1 & $/ \mathrm{t} /$ & $/ \mathrm{t} /$ & $/ \mathrm{t} /$ & $/ \mathrm{t} /$ & $/ \mathrm{d} /$ & $/ \mathrm{d} /$ \\
\hline & & than & 2 & $/ \mathrm{d} /$ & $/ \mathrm{t} /$ & /d/ & $/ \mathrm{d} /$ & $/ \mathrm{d} /$ & $/ \mathrm{d} /$ \\
\hline & & the & 5 & $/ \mathrm{d} /$ & $/ \mathrm{d} /$ & $/ \mathrm{d} /$ & $/ \mathrm{d} /$ & $/ \mathrm{d} /$ & $/ \mathrm{d} /$ \\
\hline & & those & 6 & $/ \mathrm{d} /$ & $/ \mathrm{d} /$ & $/ \mathrm{d} /$ & $/ \mathrm{d} /$ & $/ \mathrm{d} /$ & $/ \mathrm{d} /$ \\
\hline & & those & 7 & $/ \mathrm{d} /$ & $/ \mathrm{d} /$ & $/ \mathrm{d} /$ & $/ \mathrm{d} /$ & $/ \mathrm{d} /$ & $/ \mathrm{d} /$ \\
\hline & & them & 8 & $/ \mathrm{t} /$ & $/ \mathrm{d} /$ & $/ \mathrm{d} /$ & $/ \mathrm{d} /$ & $/ \mathrm{d} /$ & $/ \mathrm{d} /$ \\
\hline & & within & 9 & $/ \mathrm{t} /$ & $/ \mathrm{t} /$ & $/ \mathrm{d} /$ & $/ \mathrm{d} /$ & $/ \mathrm{d} /$ & $/ \mathrm{d} /$ \\
\hline & & within & 18 & /d/ & $/ \mathrm{t} /$ & $/ \mathrm{d} /$ & $/ \mathrm{d} /$ & $/ \mathrm{d} /$ & $/ \mathrm{d} /$ \\
\hline & & than & 19 & $/ \mathrm{d} /$ & /d/ & $/ \mathrm{d} /$ & $/ \mathrm{d} /$ & $/ \mathrm{d} /$ & $/ \mathrm{d} /$ \\
\hline
\end{tabular}

From the findings above, the six participants made errors in pronouncing both consonant sounds. The words are categorized as the consonant sound $/ \theta /$. Almost all participants pronounced it with a voice /t/. However, in some words like "with" and 
"breath," sometimes they sounded inconsistent, some sounded unmistakable, some sounded very soft, like pointing at a sound $/ \theta /$, but the researcher could still catch a sound $/ \mathrm{t} /$. In the consonant sound category $/ ð /$, the words "the" and "those" sound like replacing the dental sound /ð/ with the alveolar sound /d/. The words "within" and "than" still sound like a sound /d/, but not in all parts. Some of the lyrics sound like a ringing $/ \mathrm{t} /$.

Table 4. Consonant Sounds produced in the Song 'The Seal Lullaby" before the Introduction of Hijaiyah

\begin{tabular}{|c|c|c|c|c|c|c|c|c|c|}
\hline \multirow{2}{*}{ No } & \multicolumn{3}{|c|}{ Consonant sounds } & \multirow{2}{*}{ SF } & \multirow{2}{*}{$\mathrm{RF}$} & \multirow{2}{*}{ NA } & \multirow{2}{*}{$\mathrm{AK}$} & \multirow{2}{*}{$\mathrm{HA}$} & \multirow{2}{*}{$\mathrm{NH}$} \\
\hline & Consonant & Words & Line & & & & & & \\
\hline \multirow{4}{*}{1.} & \multirow{4}{*}{ / / / - / } & thee & 1 & $/ \mathrm{t} /$ & $/ \mathrm{t} /$ & - & - & $/ \mathrm{t} /$ & $/ \mathrm{t} /$ \\
\hline & & thy & 7 & - & - & - & $/ \mathrm{t} /$ & - & - \\
\hline & & thy & 8 & $/ \mathrm{t} /$ & $/ \mathrm{t} /$ & $/ \mathrm{t} /$ & $/ \mathrm{t} /$ & $/ \mathrm{t} /$ & $/ \mathrm{t} /$ \\
\hline & & thee & 10 & $/ \mathrm{t} /$ & $/ \mathrm{t} /$ & - & - & $/ \mathrm{t} /$ & $/ \mathrm{t} /$ \\
\hline \multirow{7}{*}{2.} & \multirow{7}{*}{ /ð/ - / / } & the & 3 & - & - & - & - & $/ \mathrm{d} /$ & - \\
\hline & & that & 3 & - & - & - & - & $/ \mathrm{d} /$ & - \\
\hline & & the & 4 & $/ \mathrm{d} /$ & /d/ & $/ \mathrm{d} /$ & $/ \mathrm{d} /$ & $/ \mathrm{d} /$ & $/ \mathrm{d} /$ \\
\hline & & the & 4 & - & - & - & - & $/ \mathrm{d} /$ & - \\
\hline & & there & 7 & - & - & - & $/ \mathrm{d} /$ & - & - \\
\hline & & the & 10 & $/ \mathrm{d} /$ & $/ \mathrm{d} /$ & $/ \mathrm{d} /$ & $/ \mathrm{d} /$ & $/ \mathrm{d} /$ & $/ \mathrm{d} /$ \\
\hline & & the & 10 & $/ \mathrm{d} /$ & $/ \mathrm{d} /$ & /d/ & $/ \mathrm{d} /$ & $/ \mathrm{d} /$ & $/ \mathrm{d} /$ \\
\hline \multirow{2}{*}{3.} & \multirow{2}{*}{ | / | I/ } & hush & 1 & $/ \mathrm{g} /$ & ISI & - & - & $/ \mathrm{J} /$ & $/ \delta /$ \\
\hline & & shark & 10 & $/ \mathrm{d} /$ & /g/ & - & - & $/ S /$ & $/ \int /$ \\
\hline
\end{tabular}

On the second song, The Seal Lullaby, there were three kinds of consonant sounds found. As for the first consonant sound $/ \theta /$, six participants could ring this sound, but it sounded vaguely the other sounds heard as the consonant $/ \mathrm{t} /$. The second consonant sound is /ð/, as in the first song, all of the six participants were sounding the words with a consonant $/ d /$. In the third category, consonant sound $/ \delta /$, as seen in table 2 , those six participants could pronounce this sound correctly at this session. It is understandable because the kind of palatoalveolar voice is familiar in the ear of the participants. It is also worth noting on the second song that there is a sign "-," which means that not all the song parts get the same lyrics according to the type of voice of each participant, soprano, alto, tenor, and bass based on the partitur.

From the tables above, it can be seen that almost all the participants sounded the target words with different consonants. For example, as for the word "the", they sound it as the consonant /d/ Clearly, some of them also sounded very soft. Whereas the phrase "the" should be pronounced with a dental sound /ð/. Some participants pronounced the word "within," which was supposed to be in the sound /ð/, but they used the sound / $t /$, and some used the sound $/ \mathrm{d} /$. The use of the Alveolar /d/ and / $/ \mathrm{t}$ of the participants is understandable because the tongue's position when producing the sounds is on the alveolar ridge, which lies behind the teeth. This is highly likely to happen because of the habit 
of participants when using their mother tongue.

\subsection{English Pronunciation after the Introduction of Hijaiyah Consonants}

After doing the first activity, the researchers began introducing the participants to the Hijaiyah-Consonant chart. First, the researchers explained the five types (table 5) and gave examples to the participants.

Table 5. English and Hijaiyah Corresponding Consonant Chart

\begin{tabular}{|c|c|c|}
\hline $\begin{array}{l}\text { English } \\
\text { Consonant } \\
\text { Sound }\end{array}$ & $\begin{array}{c}\text { Hijaiyah } \\
\text { Consonant } \\
\text { Sound }\end{array}$ & Example \\
\hline$/ \theta /$ & ث & $\begin{array}{c}\text { thank } \\
\text { think } \\
\text { bath }\end{array}$ \\
\hline /ð/ & $\dot{j}$ & $\begin{array}{l}\text { father } \\
\text { brother } \\
\text { than }\end{array}$ \\
\hline$/ 2 /$ & ش & share \\
\hline
\end{tabular}

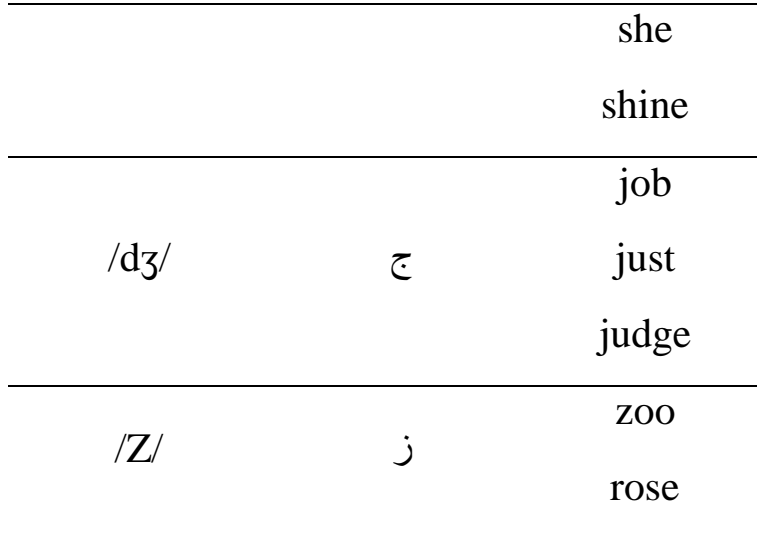

After introducing the five types of consonants, the researchers then directed the participants to the Hijaiyah Consonant sounds that appeared on two songs that they had sung before. In song's the lyrics, the words with the Consonants $/ \theta /, / ठ /$, and $/ \delta /$ are bold-typed. The participants were also asked to practice the pronunciation of the words before they applied them to a song. Finally, the researcher asked the participants to sing and insert the consonant material simultaneously. Once again, the researchers recorded the sound of the participants when singing. From the sound recording, the results of the data are in the form of a table 6 below.

Table 6. Consonant Sounds Produced in the Song 'When I Sing' after the Introduction of Hijaiyah Consonants

\begin{tabular}{|c|c|c|c|c|c|c|c|c|c|}
\hline \multirow{2}{*}{ No } & \multicolumn{3}{|c|}{ Consonant sounds } & \multirow{2}{*}{ SF } & \multirow{2}{*}{$\mathbf{R F}$} & \multirow{2}{*}{$\mathbf{C Y}$} & \multirow{2}{*}{$\mathbf{A Y}$} & \multirow{2}{*}{ HA } & \multirow{2}{*}{ NH } \\
\hline & Consonant & Words & Line & & & & & & \\
\hline \multirow{7}{*}{1.} & \multirow{7}{*}{ / / / - / } & thousand & 3 & $/ \theta /$ & $/ \theta /$ & $/ \theta /$ & $/ \theta /$ & $/ \theta /$ & $/ \theta /$ \\
\hline & & with & 13 & $/ \theta /$ & $/ \theta /$ & $/ \theta /$ & $/ \theta /$ & $/ \theta /$ & $/ \theta /$ \\
\hline & & with & 14 & $/ \theta /$ & $/ \theta /$ & $/ \theta /$ & $/ \theta /$ & $/ \theta /$ & $/ \theta /$ \\
\hline & & breath & 14 & $/ \theta /$ & $/ \theta /$ & $/ \theta /$ & $/ \theta /$ & $/ \theta /$ & $/ \theta /$ \\
\hline & & with & 15 & $/ \theta /$ & $/ \theta /$ & $/ \theta /$ & $/ \theta /$ & $/ \mathrm{t} /$ & $/ \mathrm{t} /$ \\
\hline & & with & 21 & $/ \theta /$ & $/ \theta /$ & $/ \theta /$ & $/ \theta /$ & $/ \mathrm{t} /$ & $/ \mathrm{t} /$ \\
\hline & & thousand & 11 & $/ \theta /$ & $/ \theta /$ & $/ \theta /$ & $/ \theta /$ & $/ \theta /$ & $/ \theta /$ \\
\hline \multirow{3}{*}{2.} & \multirow{3}{*}{ /ð/ - / / } & within & 1 & $/$ /ð/ & $/$ /ð/ & /ð/ & /ð/ & /ð/ & /ð/ \\
\hline & & than & 2 & /ð/ & /ð/ & /ð/ & /ð/ & /ð/ & /ð/ \\
\hline & & the & 5 & /ð/ & /ð/ & /ð/ & /ð/ & /ð/ & /ð/ \\
\hline
\end{tabular}




\begin{tabular}{|c|c|c|c|c|c|c|}
\hline those & 6 & /ð/ & /ð/ & /ð/ & /ð/ & /ð/ \\
\hline those & 7 & /ð/ & /ð/ & /ð/ & /ð/ & /ð/ \\
\hline them & 8 & /ð/ & /ð/ & /ð/ & /ð/ & /ð/ \\
\hline within & 9 & /ð/ & /ð/ & /ð/ & /ð/ & /ð/ \\
\hline within & 18 & /ð/ & /ð/ & /ð/ & /ð/ & /ð/ \\
\hline than & 19 & /ð/ & /ð/ & /ð/ & /ð/ & /ð/ \\
\hline
\end{tabular}

After introducing Hijaiyah consonants in the song 'When I Sing', in the consonant sound $/ \theta /$, four participants pronounced all the words correctly. As in the other two singers, the six words sounded right, and the two words 'with,' two participants still made errors, they sounded $/ t /$. As for the following consonant /ð/, all of the six singers pronounced the words accurately. At the same time, two of the participants sounded equivocal.

Table 7. Consonant Sounds Produced in the Song "The Seal Lullaby" after the Introduction of Hijaiyah Consonants

\begin{tabular}{|c|c|c|c|c|c|c|c|c|c|}
\hline \multirow{2}{*}{ No } & \multicolumn{3}{|c|}{ Consonant sounds } & \multirow{2}{*}{ SF } & \multirow{2}{*}{$\mathbf{R F}$} & \multirow{2}{*}{ NA } & \multirow{2}{*}{ AK } & \multirow{2}{*}{ HA } & \multirow{2}{*}{ NH } \\
\hline & Consonant & Words & Line & & & & & & \\
\hline \multirow{4}{*}{1.} & \multirow{4}{*}{ / / / - / } & thee & 1 & $/ \theta /$ & $/ \theta /$ & - & - & $/ \theta /$ & $/ \theta /$ \\
\hline & & thy & 7 & - & - & - & $/ \theta /$ & - & - \\
\hline & & thy & 8 & $/ \theta /$ & $/ \theta /$ & $/ \theta /$ & $/ \mathrm{t} /$ & $/ \theta /$ & $/ \theta /$ \\
\hline & & thee & 10 & $/ \theta /$ & - & - & - & $/ \theta /$ & $/ \theta /$ \\
\hline \multirow{7}{*}{2.} & \multirow{7}{*}{ /ð/ - / / / } & the & 3 & - & - & - & - & /ð/ & - \\
\hline & & that & 3 & - & - & - & - & /ð/ & - \\
\hline & & the & 4 & /ð/ & /ð/ & /ð/ & /ð/ & /ð/ & /ð/ \\
\hline & & the & 4 & - & - & - & - & /ð/ & - \\
\hline & & there & 7 & - & - & - & /ð/ & - & - \\
\hline & & the & 10 & /ð/ & /ð/ & /ð/ & $/ \mathrm{d} /$ & /ð/ & /ð/ \\
\hline & & the & 10 & /ð/ & /ð/ & /ð/ & $/ \mathrm{d} /$ & /ð/ & /ð/ \\
\hline \multirow{2}{*}{3.} & \multirow{2}{*}{ /ش/ - / / } & hush & 1 & Jl & $/ \mathrm{s} /$ & - & - & S/ & Jl \\
\hline & & shark & 10 & Jl & fl & - & - & d/ & fl \\
\hline
\end{tabular}

On the song "The Seal Lullaby," the participants are also easy to practice. It can be seen on the table 7 that almost all the participants pronounced the three Hijaiyahconsonants correctly. However, there were still some flaws in some parts. For example, in the lyrics "thy" on line 8, one participant still sounded like /t/. There was also missing in the consonant $/ ð /$ in which one participant still sounded like /d/. The last mistake can be 
found in the consonant $/ \delta /$ where one participant rang it with the voice /s/. However, in the former data, the participant sounded right. In conclusion, the four participants sounded correctly.

Based on the research findings above, there were two discussion points; English consonant sounds produced by the university choir members before the introduction of Hijaiyah consonants and English consonant sounds produced by the university choir members after the introduction of Hijaiyah consonants.

The previous study by Gusdian and Lestiono (2018) used different techniques that had been applied to introduce the English and Hijaiyah consonant chart (reading a short passage, tongue twister game, the use of phonetic transcription, sound imitation, and pronunciation drill). This technique was confirmed by Szyszka (2015) about the active English pronunciation learning strategies, one of them is singing a song, is bringing success in sound production. As a result, the participants have become more aware of their proficiency in Arabic consonant sounds to achieve accurate English sounds. Whereas, the technique that the researcher used in this current study was singing songs. From the result above, it showed that the participants were easy to transfer the English-Hijaiyah consonant sounds to singing. Nevertheless, the similarity of the research finding was to know the participant's English pronunciation before and after the introduction of Hijaiyah consonants.

Based on the findings presented in the English pronunciation of the university choir members before the prelims of Hijaiyah Consonants, the researcher found from the two songs most all the singers showed some inconsistencies in producing the targeted words. Some of the singers pronounced some of the words correctly, while they were mispronouncing in others. For example, six out of eight singers were sounding the words "hush" and "shark" in the consonant / / that appeared in the song "The Seal Lullaby For the other singers, six out of eight, who sang the song "When I Sing," no one could pronounce the targeted sounds accurately. This condition can be understood because they might find difficulties in pronouncing the targeted words since the language features are diverse from their first language, Bahasa Indonesia. Kosasih (2017) explains the hardship faced by Indonesian students appears in spelling English words because it happens from the unfamiliar phonemes between English and Bahasa Indonesia phonemes. The differences between the two features create difficulties for students in achieving native English sounds.

From the second data analysis, English Pronunciation after the prelims of Hijaiyah consonants, the participants could understand the concepts presented in the Hijaiyah-Consonant chart because they have had the basic skills gained from the learning process of learning Al-Quran since childhood. For that reason, It could help the participants understand the given material. Moreover, knowing and understanding this method have taken a short time to be applied and practiced in singing the targeted songs effortlessly. Lestiono and Gusdian (2017) showed that the acknowledgment of Arabic that the participants got from an Islamicbased school accommodated them to produce accurate English sounds.

In the data from table 6 and $\underline{7}$ above, it is apparent that there are significant differences in the results obtained before and after introduction. Although there was a mistake in some parts of the word "with," there were still less consistent in the sound $/ \theta /$, but they sounded correct in other lyrics. This finding shows that the singers figured out their knowledge about Hijaiyah sounds. With this insight, they used it to help them pronounce the targeted words in the song's lyrics. As a result, the Hijaiyah consonants were facilitating the singers to pronounce English words. It also supports the previous study by Gusdian and Lestiono (2018), which shows a similar result. This finding, also established by Yeaqub (2018), explains that English and Arabic have similar sounds; like $/ \theta /, / \delta /$, and $/ \mathrm{J} /$ do exist in both languages. 
Therefore, these similarities can help Arabic students to speak English correctly.

There are also some unique findings. For example, in table five, one singer made a mistake in the word 'shark,' which is supposed to be / $/$ / like the singer did in table 1 , and the singer pronounced it with the neighboring sound /s/. This phenomenon could occur due to the influence from their mother tongue. Sari et al. (2017) state that when Indonesian students learn English as a foreign language, some speech sounds do not exist in the Indonesian phonological system and produce some unique words. As a result, Indonesian learners often replace particular sounds that are difficult to pronounce. Also, it is due to the different phonological systems between English and Indonesian. Another unique finding is, besides helping the singer pronounce the English words correctly, the way of pronouncing Arabic consonants also can help the singers get the right articulation place, which can affect their singing technique. Riyani \& Prayogo (2013) mention that some factors need to be considered in singing techniques, such as intonation, vocal quality, resonation, phonation, body posture, breathing, and articulation. The singing technique involves jaw structure, stomach contractions, and airways in use (Dayme, 2009). Dental voice $/ \theta /$ and $/ ð /$ are produced by placing the tongue tip behind the upper front teeth. This sound-producing technique helps the singer to lift up their soft palate to create the right resonance voice upon singing.

\section{Conclusion}

From the data analysis, the English pronunciation of the university choir members before introduction showed that they were some mispronouncing on targeted words, but there were some participants who sounded right. Participants who knew about Arabic, as they learn Al-Quran, could easily understand the concept of Hijaiyah consonants, particularly/ث/, /ذ/, and /ش/, which could help them to produce these sounds $/ \theta /, / / /$, and $/ \int /$ accurately. Aside from accommodating the participants to pronounce the words, ringing the dental sounds $/ \theta /$ and $/ \delta /$ facilitates them, making the correct articulation, and producing good resonance. The researchers also reveals that the participant's abilities are different from each other. Their pronunciation results are diverse because there are factors that could cause them to mispronounce words. Those factors are the differences between the English and Indonesian phonological systems, and the participants use their mother language as daily talk instead of English. The further study is expected to be applied on how English-Hijaiyah consonant chart as mediator in other circumstances in English learning.

\section{References}

Al-Zoubi, D. S. M. (2019). The speech sounds of Arabic language and their effect on learning English pronunciation: A contrastive analysis. International Journal of Humanities and Social Science, 9(1), 15-27. https://doi.org/10.30845/ijhss.v9n1p2

Bailey, K., \& Nunan, D. (2019). Practical English language teaching speaking. 104.

Crystal, D. (2003). English as a global language. English as a global language, 1999 , 389-393. https://doi.org/10.1017/cbo9780511486 999

Dajani, B. A. S., \& Omari, F. M. A. (2013). A comparison between the Arabic and the English language. Procedia - Social and Behavioral Sciences, 82(July), 701-706.

https://doi.org/10.1016/j.sbspro.2013.0 6.332

Dayme, M. (2009). Dynamics of the singing voice (Fifth Edition). https://doi.org/10.1007/978-3-21188729-5

Derakhshan, A., Khalili, A. N., \& Beheshti, F. (2016). Developing EFL learner's speaking ability, accuracy and fluency. 
English Language and Literature Studies, $\quad 6(2), \quad 177$. https://doi.org/10.5539/ells.v6n2p177

Dzanic, N. D., \& Pejic, A. (2016). The effect of using songs on young learners and their motivation for learning English. NETSOL: New Trends in Social and Liberal Sciences, 1(2), 40-54. https://doi.org/10.24819/netsol2016.8

Farmand, Z., \& Pourgharib, B. (2013). The effect of English learners pronunciation. International Journal of Basic Sciences \& Applied Research, 2(9), 840-845.

Gilakjani, A., Ahmadi, S., \& Ahmadi, M. (2011). Why is pronunciation so difficult to learn? English Language Teaching, 4(3), 74-83. https://doi.org/10.5539/elt.v4n3p74

Gilakjani, A. P. (2016). English pronunciation instruction: A literature review. International Journal of Research in English Education, 1(1), 16. http://ijreeonline.com/article-1-21en.html

Gusdian, M.A, R. I., \& Lestiono, R. (2019). Cater for proper English pronunciation in the primary school level: Put to use Arabic consonants. KEMBARA Journal of Scientific Language Literature and Teaching, 5(2), 254. https://doi.org/10.22219/kembara.vol5. no2.254-261

Gusdian, R. I., \& Lestiono, R. (2018). The use of Arabic consonant sounds to arrive at English pronunciation: A case study on Indonesian EFL students in Tertiary Level. Erudio Journal of Educational Innovation, 5(2), 1-9. https://doi.org/10.18551/erudio.5-2.1

Jahan, N. (2003). Teaching and learning pronunciation in ESL / EFL classes of Bangladesh. Journal of Education and Practice, 2(3), 36-46. www.iiste.org

Javed, F. (2013). Arabic and English phonetics: A comparative study. The
Criterion An International Journal in

English, Vol. 4,(Issue-IV). http://www.the-

criterion.com/V4/n4/Javed.pdf

Kosasih, M. M. (2017). Native language interference in learning English pronunciation: A case study at a private university in West Java, Indonesia. International Journal of Education and Research, 5(2), 135-150.

Kumar, D. T. J. (2013). Teaching speaking : from fluency to accuracy. Teaching Speaking From Fluency To Accuracy, LV/ 6(November 2013), 16-21.

Lestiono, R., and Gusdian, R. (2017). Arriving at English pronunciation by means of Arabic consonant sounds: A case study on efl students in Indonesian context.7th International Conference on Literature, Humanities, Social Sciences and Education (LHSSE-2017). Retrieved from http://eprints.umm.ac.id/id/eprint/3660 7

Moravcsik, E. A. (2012). Introducing language typology. Introducing Language Typology. https://doi.org/10.1017/cbo9780511978 876

Mulansari, I., Basri, H., \& Hastini. (2014). The Analysis of the first year students, errors in pronouncing English words. $E$ Journal of English Language Teaching Society (ELTS), 2(3), 1-16. http://jurnal.untad.ac.id/jurnal/index.ph p/ELTS/article/view/3048/2121

Mulatsih, D. (2018). Pronunciation ability by using English song in Indonesian student of Unswagati Cirebon. Academic Journal Perspective: Education, Language, and Literature, 2(2), 294. https://doi.org/10.33603/perspective.v2 i2.1665

Pennington, M., \& Rogerson-Revell, P. 
(2019). English pronunciation teaching and research: Contemporary perspectives. In Palgrave Macmillan.

Riyani, I. O., \& Prayogo, J. A. (2013). An analysis pf pronunciation errors made by Indonesian singers in Malang in singing English Song. Journal Online Universitas Negeri Malang, 4(2).

Sabir, I., \& Alsaeed, N. (2014). A Brief Description of Consonants in Modern Standard Arabic. Linguistics and Literature Studies, 2(7), 185-189. https://doi.org/10.13189/1ls.2014.02070 2

Sari, R. A., Adnyani, N. L. P. S., Suputra, P. E. D., Pastika, I. W., \& Suparwa, I. N. (2017). A course in english phonetics and phonology for Indonesian students (Issue January 2017).

Shen, Y. (2013). Balancing accuracy and fluency in english classroom teaching to improve Chinese non-english majors' oral english ability. Theory and Practice in Language Studies, 3(5), 816-822. https://doi.org/10.4304/tpls.3.5.816822

Sihombing, M. G. (2013). The correlation between the students' pronunciation mastery and their ability in speaking. International Conference on Education and Language (ICEL), 2(9), 16891699.

Simensen, A. M. (2010). Fluency: An aim in teaching and a criterion in assessment. Acta Didactica Norge, 4(1), 1-13. https://doi.org/10.5617/adno.1048

Supeno. (2008). Using songs to improve students' pronunciation. Letras, 2(44), 93-108.

Szyszka, M. (2015). Good English pronunciation users and their pronunciation learning strategies. Research in Language, 13(1), 93-106. https://doi.org/10.1515/rela-2015-0017

Usha, K. (2016). Communication barriers.
Journal of English Language and Literature, 3(2), 74-76.

Yeaqub, M. (2018). Similarities and dissimilarities of English and Arabic alphabets in phonetic and phonology: A comparative study. 2(2), 94-105. http://journal2.um.ac.id/index.php/alara bi/article/viewFile/6675/3377 